einstein

Official Publication of the Instituto Israelita

de Ensino e Pesquisa Albert Einstein

ISSN: 1679-4508 | e-ISSN: 2317-6385

\title{
Importance of oral health care in times
}

\section{of COVID-19}

\author{
Importância dos cuidados com a saúde oral em tempos \\ de COVID-19
}

Fabiano Vieira Vilhena' ${ }^{1}$ Bernardo da Fonseca Orcina² ${ }^{2}$ Verônica Caroline Brito Reia², Mariana Ragghianti Zangrando², Rodrigo Cardoso de Oliveira², Paulo Sérgio da Silva Santos²

${ }^{1}$ TRIALS - Saúde Bucal \& Tecnologias, Bauru, SP, Brazil.

2 Faculdade de Odontologia de Bauru, Universidade de São Paulo, Bauru, SP, Brazil.

DOI: 10.31744/einstein_journal/2021CE6706

Dear Editor,

The infection caused by the severe acute respiratory syndrome coronavirus 2 (SARS-CoV-2) in the host cells occurs by interaction of cleaved viral protein spike with the receptors of angiotensin-converting enzyme 2 (ACE2) and of transmembrane serine protease 2 (TMPRSS2). The presence of ACE2 and TMPRSS2 in the salivary glands make them a reservoir for SARS-CoV-2, leading to cell endocytosis and the viral replication cycle. This knowledge is relevant to better understand and develop strategies to mitigate contamination by droplets. ${ }^{(1)}$

Since the oral cavity is closely related to the progression of the coronavirus 2019 disease (COVID-19), and the oral health status is associated to severity of the condition,,$^{(2)}$ adopting preventive measures, such as maintenance of oral health by chemical-mechanical control of oral microbiota, becomes a relevant issue..$^{(3-6)}$

The medical literature has shown the use of broad-spectrum antiseptic mouthwashes demonstrated laboratory results and clinical efficacy in reducing the viral load and symptoms of COVID-19 ${ }^{(3-6)}$ (Table 1). The evidence is as recent as the pandemic.

Therefore, it seems maintenance of oral health, with the correct strategies, does not lead to contraindications or evidence of non-effectiveness in prevention of COVID-19.

Table 1. List of antiseptic mouthwashes used and their respective benefits in treating COVID-19 patients

\begin{tabular}{|c|c|}
\hline Antiseptic mouthwash & Benefits \\
\hline Povidone-iodine (PVP-||(3) & Reducing viral load \\
\hline Chlorhexidine ${ }^{(3)}$ & Reducing viral load \\
\hline ß-cyclodextrin/Citrox ${ }^{(4)}$ & Reducing viral load \\
\hline Hydrogen peroxide ${ }^{|3\rangle}$ & Reducing viral load \\
\hline $\begin{array}{l}\text { Anionic phthalocyanine derivative (APD) - } \\
(\text { Phtalox })^{(5,6)}\end{array}$ & $\begin{array}{l}\text { Reducing viral load, reducing symptoms, reducing severity of disease, } \\
\text { reducing length of hospital stay }\end{array}$ \\
\hline
\end{tabular}

\section{AUTHORS' INFORMATION}

Vilhena FV: http://orcid.org/0000-0003-3840-3633

Orcina BF: http://orcid.org/0000-0003-3367-483X

Reia VC: http://orcid.org/0000-0003-1352-5474

Zangrando MR: http://orcid.org/0000-0003-0286-7575

Oliveira RC: http://orcid.org/0000-0003-3070-5960

Santos PS: http://orcid.org/0000-0002-0674-3759 


\section{REFERENCES}

1. Matuck BF, Dolhnikoff M, Duarte-Neto AN, Maia G, Gomes SC, Sendyk DI, et al. Salivary glands are a target for SARS-CoV-2: a source for saliva contamination. J Pathol. 2021;254(3):239-43.

2. Kamel A, Basuoni A, Salem Z, AbuBakr N. The impact of oral health status on COVID-19 severity, recovery period and C-reactive protein values. Br Dent J. 2021:1-7.

3. Mateos-Moreno MV, Mira A, Ausina-Márquez V, Ferrer MD. Oral antiseptics against coronavirus: in vitro and clinical evidence. J Hosp Infect. 2021;113: 30-43. Review.

4. Carrouel F, Valette M, Gadea E, Esparcieux A, Illes G, Langlois ME, et al.
Use of an antiviral mouthwash as an additional barrier measure in the SARS-CoV-2 transmission in adults with asymptomatic to mild COVID-19: a multicenter, randomized, double-blind controlled trial. Clin Microbiol Infect. 2021;27(10):1494-501.

5. da Fonseca Orcina B, Vilhena FV, Cardoso de Oliveira R, Marques da Costa Alves L, Araki K, Toma SH, et al. A phthalocyanine derivate mouthwash to gargling/rinsing as an option to reduce Clinical Symptoms of COVID-19: case series. Clin Cosmet Investig Dent. 2021:13;47-50.

6. da Silva Santos PS, da Fonseca Orcina B, Machado RR, Vilhena FV, da Costa Alves LM, Zangrando MS, et alL. Beneficial effects of a mouthwash containing an antiviral phthalocyanine derivative on the length of hospital stay for COVID-19: randomised trial. Sci Rep. 2021;11(1):19937. 